зика : Часть 1 / В. К. Кобушкин. - Изд-во Ленинградского университета, 1970. - 238 с. 7. Митрофанов А. Вверх по наклонной плоскости / А. Митрофанов // Квант. - 1980. - № 2. - С. 24-25.

УДК 372.851

Н. В. Рашевська, кандидат пед. наук, ДВНЗ «Криворізький національний університет»,

В. В. Ткачук, acnipaнm, Інститут інформаційних технологій $i$ засобів навчання НАПН України

\title{
ТЕХНОЛОГІЇ МОБІЛЬНОГО НАВЧАННЯ
}

У статті запропоновано тлумачення поняття «мобільне навчання», наведено його переваги та недоліки, розглянуто кілька напрямів реалізащіі мобільного навчання, зокрема для побудови моделі зміманого навчання.

Ключові слова: мобільне навчання, мобільні інформаційнокомунікаційні технології.

В статье приведены определения понятия «мобильное обучение», указаны его преимущества и недостатки, рассмотрены несколько направлений реализации мобильного обучения, в частности для построения модели смешанного обучения.

Ключевые слова: мобильное обучение, мобильные информачионнокоммуникационные технологии.

The article contains several definitions of mobile learning, shows its advantages and disadvantages, discussed several areas of the implementation of mobile learning, in particular, to construct a model of blended learning.

Key words: mobile learning, mobile information and communication technologies.

Як зазначено в проекті Національної стратегії розвитку освіти в Україні на 2012-2021 роки, метою Національної стратегії розвитку освіти є: підвищення доступності якісної, конкурентоспроможної освіти для громадян України відповідно до вимог інноваційного розвитку суспільства, економіки, кожного громадянина; забезпечення особистісного розвитку людини згідно з ії індивідуальними задатками, здібностями, потребами на основі навчання упродовж життя [3].

Аналіз останніх досліджень показав, що пріоритетом розвитку освіти $\epsilon$ впровадження сучасних інформаційнокомунікаційних технологій (IКT), зокрема - технологій та засобів мобільного навчання, які забезпечують удосконален- 
ня навчально-виховного процесу, доступність та ефективність освіти, підготовку молодого покоління до життєдіяльності в інформаційному суспільстві.

Метою статті є дослідження переваг та недоліків мобільного навчання.

Мобільне навчання $є$ новою освітньою парадигмою, на основі якої створюється нове навчальне середовище, де студенти можуть отримати доступ до навчальних матеріалів у будь-який час та в будь-якому місці, що робить сам процес навчання всеохоплюючим та мотивує до безперервної освіти та навчання протягом усього життя.

Передумови для мобільного навчання закладено в 70-х роках минулого століття, коли Алан Кей запропонував ідею комп'ютера розміром із звичайну книгу для освітніх цілей. У 1990-х роках із появою кишенькових персональних комп'ютерів починається впровадження мобільного навчання в навчальний процес університетів, з'являються перші навчальні проекти для реалізації мобільного навчання. Започатковано дослідження в галузі мобільного навчання зарубіжних науковців: Т. Андерсон розробляє теоретико-методичні засади електронного навчання, М. Шарплз і Дж. Еттевел вивчають вплив мобільних засобів на процес навчання; М. Рагус розробляє австралійський державний стандарт мобільного навчання; Дж. Тракслер розглядає перспективи розвитку мобільного навчання [1].

У літературі існує багато тлумачень поняття «мобільне навчання», і спільним для них $є$ те, що за цієї технології навчання фізичне 3'єднання 3 кабельною мережею $\epsilon$ необов'язковим [11]. На думку С. Семерікова, «мобільне навчання можна визначено як підхід до навчання, що передбачає на основі мобільних електронних пристроїв створення мобільного освітнього середовища, де студенти можуть використовувати їх у якості засобу доступу до навчальних матеріалів, що містяться в Інтернеті, будь-де та будь-коли» [7, c. 119].

В. Куклєв [2] розглядає мобільне навчання як електронне навчання за допомогою мобільних засобів, незалежно від часу та місця, 3 використанням спеціального програмного забезпечення на педагогічній основі міждисциплінарного та модульного підходів.

Мобільне навчання є, з одного боку, різновидом дистанційного навчання, а $з$ іншого - електронного (рис. 1). У порі- 
внянні з електронним та дистанційним навчанням мобільне надає суб' єкту навчання більшу кількість «ступенів вільності» - вищу інтерактивність, більшу свободу руху, більшу кількість технічних засобів, основними 3 яких $\epsilon$ нетбуки, планшетні ПК, PDA (персональні цифрові помічники), аудіопрогравачі для запису та прослуховування лекцій, електронні книжки, мобільні телефони, смартфони тощо [9].

Графічно співвідношення дистанційного, електронного й мобільного навчання можна подати так:

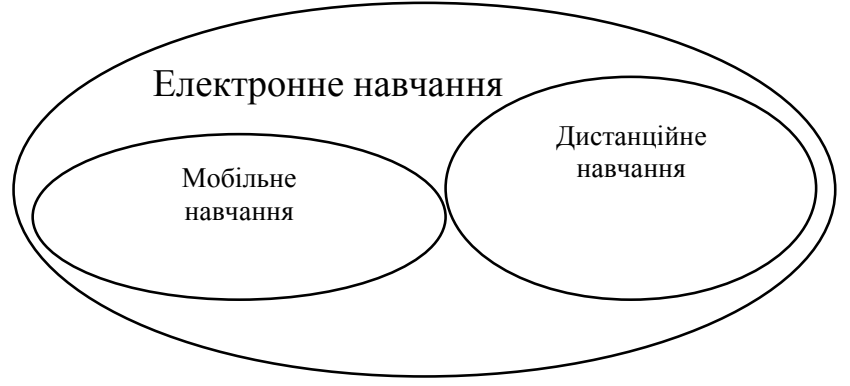

Рис. 1. Співвідношення електронного, дистанційного та мобільного навчання

Іноді виокремлюють віртуальне навчання, під яким розуміють усі форми та підходи до навчання з використанням Інтернету [10]. Ідеться про електронне навчання (за визначенням Європейської комісії), або об'єднання електронного та мобільного навчання (за визначенням С. Семерікова, який зауважує, що «мобільне навчання забезпечує більшу навчальну мобільність порівняно з електронним або традиційним навчанням» [7, с. 125]).

Унікальними властивостями мобільного навчання є:

- придатність до одночасної взаємодії як з одним студентом, так і з групою;

- можливість динамічного генерування навчального матеріалу в залежності від місцезнаходження студентів, контексту навчання та способу використання мобільних пристроїв;

- можливість виконання окремих дискретних у часі навчальних дій студентів у будь-який час і в будь-якому місці [7, c. 153-154];

- можливість реалізації змішаного навчання [6].

Н. Пейн виокремив елементи мобільного навчання, основними з яких є: 
1) студенти готові використовувати мобільні пристрої для навчання в тих випадках, коли вони не можуть скористатися книгою чи комп'ютером;

2) мобільне навчання надає можливість використання вільних проміжків часу;

3) мобільні додатки повинні бути компактними й активізуватися з того місця, на якому було перервано роботу;

4) мобільні додатки повинні бути доступними в Інтернеті, а також бути синхронізованими 3 мобільними засобами навчання [4].

Дж. Тракслер виокремлює кілька напрямів реалізації мобільного навчання:

- технологічно-орієнтоване мобільне навчання - окремі конкретні технологічні інновації, упроваджені у навчальний процес для демонстрації технічних переваг та педагогічних можливостей;

- мініелектронне навчання - мобільні, бездротові і портативні технології, які використовуються для повторного впровадження рішень і підходів, що вже використовуються у традиційних електронних засобах навчання, можливість перенесення деяких технологій електронного навчання, таких, як віртуальні навчальні середовища (VLE), на мобільні платформи (MLE) [13];

- змішане навчання - це процес навчання, за якого традиційні технології поєднуються 3 інноваційними технологіями дистанційного, електронного та мобільного навчання задля створення гармонійного поєднання теоретичного та практичного складників процесу навчання;

- неформальне, персоналізоване, ситуативне мобільне навчання - мобільні технології з додатковою функціональністю, наприклад, залежні від місця розташування;

- мобільні тренінги - технології, що використовуються для підвищення продуктивності та ефективності мобільних працівників шляхом надання матеріалів для підтримки «точно у термін» і в контексті їхніх першочергових пріоритетів;

- віддалене (сільське) розвивальне мобільне навчання мобільні технології використовуються для вирішення інфраструктурних та екологічних проблем та підтримки освіти там, де традиційні технології навчання малоефективні [5].

До особливостей мобільного навчання М. Шарплз зараховує: спільну онлайнову роботу над проектом, моблоггінг (мобільний блоггінг), персоналізоване навчання, роботу у 
групах, онлайнові дослідження, рівний доступ до навчання [12].

Основне призначення мобільного навчання полягає в тому, щоб покращити знання людини в тій галузі, у якій вона бажає, і в той момент, коли їй це потрібно.

До основних переваг мобільного навчання, у порівнянні 3 електронним, можна віднести:

- можливість навчатися будь-де та будь-коли;

- більша компактність мобільних пристроїв;

- безперервний доступ до навчальних матеріалів;

- підвищена інтерактивність навчання;

- зручність застосування послуг мобільного навчання;

- персоналізованість навчання [7, 151-152].

До організаційно-технічних недоліків мобільного навчання можна віднести:

- фрагментацію навчання: навчання вимагає концентрації та роздумів, в той час як в процесі переміщення студенти знаходяться в ситуаціях, що можуть відволікати їх увагу;

- відсутність у студентів добре розвинених навичок самоконтролю та самокерування власною пізнавальною діяльністю;

- малий розмір екрана та труднощі $з$ доступом до Інтернету: мобільні пристрої мають менші розміри екрана в порівнянні з традиційними ПК, а більшість Web-сайтів оптимізовано для екранів 3 високою роздільною здатністю;

- висока вартість початкових вкладень в організацію мобільного навчання: витрати на придбання пристрою для кожного студента, організація бездротового з'єднання 3 мережею, технічне обслуговування тощо.

Завдяки сучасним технологіям мобільного зв'язку (взаємодія «студент - викладач» здійснюється у високошвидкісному середовищі обміну повідомленнями) через мобільне навчання забезпечується високий ступінь інтерактивності, що має вирішальне значення для навчання.

Отже, можна зробити висновок, що на відміну від дистанційного навчання, мобільне навчання $є$ більш доступним для більшості студентів, а мобільні інформаційно-комунікаційні технології навчання мають достатній потенціал за гнучкістю навчання для використання та підтримки традиційного навчання.

Мобільні ІКТ доцільно використовувати для підтримки навчання за моделлю змішаного навчання, оскільки надає 
можливість поліпшувати студентам свої професійні навички, підвищити самооцінку та швидше пристосовуватися в житті.

\section{Література}

1. Куклев В. А. Становление системы мобильного обучения в открытом дистанционном образовании / В. А. Куклев // Международная научно-практическая заочная конференция «Интернет в образовании», 12 октября 2009 - 01 апреля 2010 г.; Москва : Современная гуманитарная академия; Московская финансовопромышленная академия. - Режим доступа: http://www.conf.muh.ru/091012/thesis_Kuklev.htm 2. Куклев В. А. Становление системы мобильного обучения в открытом дистанционном образовании : автореф. дис. на соискание ученой степени дра пед. наук : 13.00.01 «Общая педагогика, история педагогики и образования» / Куклев Валерий Александрович; Ульяновский государственный технический университет. - Ульяновск, 2010. - 46 с. 3. Проект Національної стратегії розвитку освіти в Україні на 20122021 роки [Електронний ресурс]. - Режим доступу: http:// iitzo.gov.ua/files/proekt_rozvitku_osviti_2012_2021_doc 4. Пэйн Н. 10 элементов мобильного обучения [Электронный ресурс] / Найджел Пейн // Дистанционное обучение : информационный портал. Режим доступа: http://distancelearning.ru/ db/el/ C89AA038334 48937C32577660010ACF1/doc.html 5. Рашевська Н. В. Мобільні інформаційно-комунікаційні технології навчання вищої математики студентів вищих технічних навчальних закладів: автореф. дис. на здобуття наук. ступеня канд. пед. наук: 13.00.10 «Інформаційнокомунікаційні технології в освіті» / Рашевська Наталя Василівна; Інститут інформаційних технологій і засобів навчання НАПН України. - К., 2011. - 21 с. 6. Рашевська Н. В. Навчання вищої математики за моделлю змішаного навчання / Н. В. Рашевська // Проблеми математичної освіти: матеріали міжнародної науково-методичної конференції, 24-26 листопада 2010 р. - Черкаси : Видавничій відділ ЧНУ ім. Б. Хмельницького, 2010. - С. 280-281. 7. Семеріков С. О. Теоретико-методичні основи фундаменталізації навчання інформатичних дисциплін у вищих навчальних закладах : дис. ... д-ра пед. наук: 13.00.02 «Теорія та методика навчання (інформатика)» / Ceмеріков Сергій Олексійович; Національний педагогічний ун-т ім. М. П. Драгоманова. - К., 2009. - 536 с. 8. Семеріков С. О. Фундаменталізація навчання інформатичних дисциплін у вищій школі: [монографія] / Сергій Олексійович Семеріков; наук. ред. академік АПН України, д. пед. н., проф. М. І. Жалдак. - Кривий Ріг : Мінерал; К. : НПУ ім. М. П. Драгоманова, 2009. - 340 с. 9. Georgiev T. M-Learning - a New Stage of E-Learning / Tsvetozar Georgiev, Evgeniya Gergieva, Angel Smrikarov // Proceedings of the 5th International Conference on Computer Systems and Technologies - CompSysTech'2004. - Rousse, 2004. - P. IV.28-1 - IV.28-5. 10. Kurbel K. Virtuality on the Students' and on the Teachers' sides : A Multimedia and 
Internet based International Master Program / Kurbel Karl // Proceedings on the 7th International Conference on Technology Supported Learning and Training; Berlin, Germany / ICEF Berlin GmbH (Eds.) Online Educa. - 2001. - November. - P. 133-136. 11. Mobile Learning: a Handbook for Educatorsand Trainers / Editedby: Agnes KukulskaHulme, John Traxler. - Routletge, 2005. - 192 p. 12. Sharples M. A Theory of Learning for the Mobile Age / Sharples M., Taylor J., Vavoula G. // The Sage Handbook of E-Learning Research / R. Andrews \& C. Haythornthwaite (eds.). - London: Sage, 2007. - P. 21-47. 13. Traxler J. Defining, Discussing, and Evaluating Mobile Learning : The moving finger writes and having writ... / Traxler J. // International Review of Research in Open and Distance Learning. - 2007. - June. Volume 8. - Number 2. 14. Yousuf M. I. Effectiveness of mobile learning in distance education / Muhammad Imran Yousuf // Turkish Online Journal of Distance Education-TOJDE. -2007. - October. Volume 8. Number 4. - P. 114-124.

УДК 004:378

\author{
Н. Т. Тверезовська, \\ доктор пед. наук, професор, \\ Наиіональний університет біоресурсів $i$ \\ природокористування України
}

\title{
ЗАКОНОМІРНОСТІ ФУНКЦІОНУВАННЯ ІНФОРМАЦІЙНИХ ТЕХНОЛОГІЙ
}

У статті розглянуто інновації як передумову виникнення інформаційних технологій; розкрито їх функціонування; показано циклічний процес зародження $і$ згасання інформаиійних технологій.

Ключові слова: інновачії, інформачійні технології, ииклічність, фундаментальність.

В статье рассмотрены инновачии как предпосылки возникновения информационных технологий; раскрыто их функиионирование, показан циклический процесс зарождения и угасания информачионных технологий.

Ключевые слова: инновачии, информачионные технологии, иикличность, фундаментальность.

The article describes the innovation as a prerequisite for the birth of information technology is considered, their operation is disclosed, a cyclic process of birth and decay of information technology is shown.

Key words: innovation, information technology, cyclical, fundamental.

Умови існування людства, що вступило у XXI століття, висувають нові вимоги до вищої освіти. Глибоке усвідомлення інноваційних явищ, уміння їх розв'язувати за допомогою 